\title{
Crystal structure of uranyl-oxide mineral wölsendorfite revisited
}

\author{
JAKUB PLÁŠIL \\ Fyzikální ústav AV ČR v.v.i., Na Slovance 2, 18221 Praha 8; e-mail: plasil@fzu.cz
}

PLAŠIL J (2020) Crystal structure of uranyl-oxide mineral wölsendorfite revisited. Bull Mineral Petrolog 28(2): 322-330 ISSN 2570-7337

\begin{abstract}
The crystal structure of the rare supergene $\mathrm{Pb}^{2+}$-containing uranyl-oxide mineral wölsendorfite has been revisited employing the single-crystal X-ray diffraction. The new structure refinement provided deeper insight into the complex structure of this mineral, revealing additional $\mathrm{H}_{2} \mathrm{O}$ sites in the interlayer complex and confirming the entrance of the Ca ${ }^{2+}$ into the structure. Studied wölsendorfite is orthorhombic, space group $\mathrm{Cmcm}$, with unit cell dimensions $a=14.1233(8)$ $\AA, b=13.8196(9) \AA, c=55.7953(12) \AA, V=10890.0(10) \AA^{3}$, and $Z=8$. The structure has been refined to an agreement index $(R)$ of $10.74 \%$ for 3815 reflections with $I>3 \sigma(I)$ collected using a microfocus X-ray source from the microcrystal. In line with the previous structure determination, the refined structure contains $\mathrm{U}-\mathrm{O}-\mathrm{OH}$ sheets of the wölsendorfite topology and an interstitial complex comprising nine symmetrically unique $\mathrm{Pb}$ sites, occupied dominantly by $\mathrm{Pb}^{2+}$. $\mathrm{Ne}-$ vertheless, one of the sites seems to be plausible for hosting $\mathrm{Ca}^{2+}$. Its presence has been successfully modeled by the refinement and further supported by the crystal-chemical considerations. The structural formula of wölsendorfite crystal studied is $\mathrm{Pb}_{6.07} \mathrm{Ca}_{0.68}\left[\left(\mathrm{UO}_{2}\right)_{14} \mathrm{O}_{18}(\mathrm{OH})_{5}\right] \mathrm{O}_{0.5}\left(\mathrm{H}_{2} \mathrm{O}\right)_{12.6}$, with $\mathrm{Z}=8, D_{\text {calc. }}=6.919 \mathrm{~g}^{\circ} \mathrm{cm}^{-3}$ (including theoretical $30.2 \mathrm{H}$ atoms). The rather complex structure of wölsendorfite makes it the third most complex known uranyl-oxide hydroxy-hydrate mineral.
\end{abstract}

Keywords: wölsendorfite, uranyl-oxide, crystal structure, Shinkolobwe, structure complexity, mineral associations

Received 5. 10. 2020; accepted 12. 11. 2020

\section{Introduction}

Uranyl-oxide hydroxy-hydrates (further on abbreviated as UOHs) represent one of the most structurally and chemically complex families of naturally occurring $\mathrm{U}^{6+}$ phases (Plášil 2018), extremely important for the nuclear fuel waste management (see, e.g., O'Hare et al. 1988; Finch, Murakami 1999; Klingensmith et al. 2007; Kubatko et al. 2006; Maher et al. 2013; Ewing 2015). The onset of oxidation and hydration of uranium oxide, $\mathrm{UO}_{2}$ (as pitchblende or synthetic in the nuclear fuel), often produces minerals consisting of electroneutral sheets of uranyl pentagonal bipyramids (of the $\alpha-U_{3} \mathrm{O}_{8}$ type) with substantial $\mathrm{H}_{2} \mathrm{O}$ in the interlayer region, and typically little, if any, additional metal cations (Burns 2005; Krivovichev, Plášil 2013; Lussier et al. 2016; Plášil 2018a; Plášil et al. 2020). There are also particularly interesting rare cases when $\mathrm{UOHs}$ contain mixtures of $\mathrm{U}(\mathrm{IV}), \mathrm{U}(\mathrm{V})$, or $\mathrm{U}(\mathrm{VI})$ oxidation states as well (Burns et al. 1997; Burns, Finch 1999; Plášil 2017; Plášil et al. 2018). Continued alteration of uranium oxide, alteration in more chemically diverse aqueous fluids, and alteration of geologically old uranium oxide that contains substantial radiogenic lead result in the formation of uranyl-oxide hydroxy-hydrates with anionic sheets of uranyl polyhedra also containing uranyl square pyramids $\left(\beta-\mathrm{U}_{3} \mathrm{O}_{8}\right.$ type of sheets) charge-balanced by cations in the interstitial regions of the structures.

Among $\mathrm{UOHs}$ there are several very complex minerals (following the terminology of Krivovichev 2013) that belong to the group of most complex minerals in Nature. Among them, there is also the uranyl-oxide mineral wölsendorfite, $\left(\mathrm{Pb}_{6.16} \mathrm{Ba}_{0.36}\right)\left[\left(\mathrm{UO}_{2}\right)_{14} \mathrm{O}_{19}(\mathrm{OH})_{4}\right]\left(\mathrm{H}_{2} \mathrm{O}\right)_{12}$, with
2885.80 bits/cell (Plášil 2018a) and a sizeable orthorhombic unit-cell with the $c$ parameter having over $50 \AA$. Wölsendorfite has been described as a new mineral species from the Wölsendorf fluorite mining district in Bavaria, Germany, by Protas (1957). It has been reported from more than 30 localities worldwide then. Nevertheless, there is only one reliable full crystal structure determination and refinement (Burns 1999). Here, the second structure determination on the crystal of wölsendorfite from Shinkolobwe is given along with some summary of the mineral associations involved.

\section{Sample}

The crystal of wölsendorfite used in this study has been retrieved from the specimen on the holotype specimen of sayrite (RGM 13944), deposited in the collections of the Royal Museum for Central Africa in Tervuren (Belgium).

\section{Single-crystal X-ray diffraction, structure refine- ment, and complexity calculations}

A tabular fragment $(0.058 \mathrm{~mm} \times 0.041 \mathrm{~mm} \times 0.006$ $\mathrm{mm}$ ) of a reddish wölsendorfite crystal was selected under a polarized-light microscope and mounted on a glass fiber. The X-ray data collection was done at room temperature with a Rigaku SuperNova single-crystal diffractometer (MoKa radiation from a micro-focus $X$-ray tube collimated and monochromated by mirror-optics and detected by an Atlas S2 CCD detector). In line with the previous study by Burns (1999) wölsendorfite was found to be orthorhom- 
Table 1 Single-crystal data collection and structure-refinement details for wölsendorfite.

\begin{tabular}{|c|c|}
\hline \multicolumn{2}{|l|}{ Crystal data } \\
\hline Structure formula & $\mathrm{Pb}_{6.07} \mathrm{Ca}_{0.68}\left[\left(\mathrm{UO}_{2}\right)_{14} \mathrm{O}_{18}(\mathrm{OH})_{5}\right] \mathrm{O}_{0.5}\left(\mathrm{H}_{2} \mathrm{O}\right)_{12.60}$ \\
\hline Molecular weight & 5672.22 \\
\hline Crystal system & orthorhombic \\
\hline Space group & $\mathrm{Cmcm}$ \\
\hline Unit-cell parameters: $a, b, c[\AA]$ & 14.1233(8), 13.8196(9), 55.7953(12) \\
\hline Unit-cell volume $\left[\AA^{3}\right]$ & $10890.0(10)$ \\
\hline$Z$ & 8 \\
\hline Calculated density $\left[\mathrm{g} / \mathrm{cm}^{3}\right]$ & 6.932 (for above mentioned formula) \\
\hline Crystal size $[\mathrm{mm}]$ & $0.058 \times 0.041 \times 0.006$ \\
\hline$F_{000}$ & 18507 \\
\hline \multicolumn{2}{|l|}{ Data collection } \\
\hline Diffractometer & Rigaku SuperNova with Atlas S2 detector \\
\hline Temperature $[\mathrm{K}]$ & 297 \\
\hline Radiation, wavelength $[\AA]$ & $\mathrm{MoK}_{\alpha}, 0.71073(50 \mathrm{kV}, 30 \mathrm{~mA})$ \\
\hline$\theta$ range for data collection $\left[^{\circ}\right]$ & $2.92-27.67$ \\
\hline Limiting Miller indices & $h=-18 \rightarrow 17, k=-17 \rightarrow 18, I=-72 \rightarrow 73$ \\
\hline Axis, frame width $\left({ }^{\circ}\right)$, time per frame $(\mathrm{s})$ & $\omega, 1,400$ \\
\hline Total reflections collected & 60978 \\
\hline Unique reflections & 6673 \\
\hline Unique observed reflections, criterion & $3815,[I>3 \sigma(I)]$ \\
\hline Absorption coefficient [mm-1], type & 60.33; gaussian (Jana2006) \\
\hline$T_{\min } / T_{\max }$ & $0.157 / 0.693$ \\
\hline$R_{\text {int }}$ & 0.1524 \\
\hline Structure refinement by Jana2006 & Full-matrix least-squares on $F^{2}$ \\
\hline $\begin{array}{l}\text { Number of refined parameters, restraints, } \\
\text { constraints }\end{array}$ & $256,0,16$ \\
\hline$R, w R$ (obs) & $0.1074,0.1947$ \\
\hline$R, w R$ (all) & $0.1817,0.2260$ \\
\hline GOF obs/all & $1.87,1.64$ \\
\hline Weighting scheme, weights & $\sigma, w=1 /\left(\sigma^{2}(I)+0.0016 /^{2}\right)$ \\
\hline Largest diffraction peak and hole $\left(\mathrm{e}^{-} / \AA^{3}\right)$ & $24.14(0.48 \AA$ close to 040$),-18.46$ \\
\hline
\end{tabular}

Table 2 Atom coordinates, displacement parameters (in $\AA^{2}$ ) and occupation factors (occ.) for the structure of wölsendorfite.

\begin{tabular}{|c|c|c|c|c|c|c|c|c|c|c|c|}
\hline & $x / a$ & $y / b$ & $z / c$ & $U_{\text {eq }} / U_{\text {iso }}{ }^{*}$ & Occ. & $U^{11}$ & $U^{22}$ & $U^{33}$ & $U^{12}$ & $U^{13}$ & $U^{23}$ \\
\hline U1 & $0.24034(10)$ & $0.48484(9)$ & $0.42479(3)$ & $0.0080(2)$ & & $0.0132(5)$ & $0.0057(4)$ & $0.0051(4)$ & $0.0022(3)$ & $0.0001(3)$ & $0.0028(3)$ \\
\hline U2 & $0.24965(10)$ & $0.27161(10)$ & $0.46683(2)$ & $0.0080(2)$ & & $0.0132(5)$ & $0.0057(4)$ & $0.0051(4)$ & $0.0022(3)$ & $0.0001(3)$ & $0.0028(3)$ \\
\hline U3 & $0.23896(10)$ & $0.75363(10)$ & $0.39339(2)$ & $0.0080(2)$ & & $0.0132(5)$ & $0.0057(4)$ & $0.0051(4)$ & $0.0022(3)$ & $0.0001(3)$ & $0.0028(3)$ \\
\hline U4 & $0.23250(15)$ & $1.28216(14)$ & 0.25 & $0.0080(2)$ & & $0.0132(5)$ & $0.0057(4)$ & $0.0051(4)$ & $0.0022(3)$ & $0.0001(3)$ & $0.0028(3)$ \\
\hline U5 & $0.26001(11)$ & $0.52782(10)$ & $0.35864(2)$ & $0.0070(4)$ & & $0.0129(9)$ & $0.0055(7)$ & $0.0025(7)$ & $-0.0032(6)$ & $-0.0037(5)$ & $0.0024(5)$ \\
\hline U6 & $0.25185(11)$ & $0.74418(10)$ & $0.31741(3)$ & $0.0112(5)$ & & $0.0238(10)$ & $0.0016(7)$ & $0.0083(8)$ & $-0.0016(6)$ & $0.0029(7)$ & $0.0013(6)$ \\
\hline U7 & $0.23347(15)$ & 0.5 & 0.5 & $0.0127(6)$ & & $0.0121(12)$ & $0.0098(10)$ & $0.0162(11)$ & 0 & 0 & $-0.0068(9)$ \\
\hline U8 & $0.23146(11)$ & $1.00493(11)$ & $0.28722(3)$ & $0.0140(5)$ & & $0.0156(9)$ & $0.0154(8)$ & $0.0110(8)$ & $0.0073(7)$ & $-0.0013(6)$ & $-0.0070(7)$ \\
\hline $\mathrm{Pb} 1$ & 0 & $1.20064(18)$ & $0.36224(5)$ & $0.0245(9)$ & $0.949(9)$ & $0.0208(17)$ & $0.0176(14)$ & $0.0351(18)$ & 0 & 0 & $0.0008(12)$ \\
\hline $\mathrm{Pb} 2$ & 0 & $0.32995(18)$ & $0.42343(5)$ & $0.0273(10)$ & $0.956(9)$ & $0.0221(17)$ & $0.0221(15)$ & $0.038(2)$ & 0 & 0 & $-0.0010(13)$ \\
\hline Pb3 & 0 & $0.14630(19)$ & $0.49981(5)$ & $0.0279(10)$ & $0.955(9)$ & $0.0365(19)$ & $0.0323(16)$ & $0.0150(15)$ & 0 & 0 & $-0.0025(13$ \\
\hline $\mathrm{Pb} 4$ & 0.5 & $1.08655(19)$ & $0.31715(5)$ & $0.0285(10)$ & $0.936(9)$ & $0.042(2)$ & $0.0210(15)$ & $0.0223(17)$ & 0 & 0 & $-0.0021(12)$ \\
\hline Pb5 & & $0.82077(19)$ & $0.42338(5)$ & $0.0363(12)$ & $0.926(9)$ & $0.081(3)$ & $0.0194(16)$ & $0.0088(16)$ & 0 & 0 & $0.0003(12)$ \\
\hline $\mathrm{Pb} 6$ & 0.5 & $0.9624(3)$ & 0.25 & $0.044(2)$ & $0.865(13)$ & $0.056(4)$ & $0.031(3)$ & $0.044(4)$ & 0 & 0 & \\
\hline $\mathrm{Pb} 7 / \mathrm{Ca} 7$ & 0 & $1.1683(5)$ & $0.28137(12)$ & $0.052(3)$ & $\begin{array}{r}0.319(12) \\
10.681(12)\end{array}$ & $0.075(7)$ & $0.063(6)$ & $0.018(4)$ & 0 & 0 & $-0.028(4)$ \\
\hline Pb8 & 0 & $0.5988(13)$ & $0.3924(4)$ & $0.056(10)$ & $0.156(10)$ & $0.11(2)$ & $0.023(11)$ & $0.039(14)$ & 0 & 0 & $0.017(9)$ \\
\hline $\mathrm{Pb} 9$ & 0 & $0.9399(4)$ & 0.25 & $0.068(3)$ & $0.872(15)$ & $0.108(6)$ & $0.039(3)$ & $0.056(5)$ & 0 & 0 & \\
\hline
\end{tabular}


Table 2 Atom coordinates, displacement parameters (in $\AA^{2}$ ) and occupation factors (occ.) for the structure of wölsendorfite - continuation.

\begin{tabular}{|c|c|c|c|c|c|}
\hline & $x / a$ & $y / b$ & $z / c$ & $U_{\text {eq }} / U_{\text {iso }}{ }^{*}$ & Occ. \\
\hline O1 & $0.2423(18)$ & $0.5967(17)$ & $0.3956(5)$ & $0.011(6)^{*}$ & \\
\hline $\mathrm{O} 2$ & 0.5 & $1.156(2)$ & $0.2751(6)$ & $0.009(8)^{*}$ & \\
\hline $\mathrm{O} 3$ & 0 & $0.647(2)$ & $0.4418(6)$ & $0.011(8)^{*}$ & \\
\hline O4 & $0.257(2)$ & $0.849(2)$ & $0.2876(6)$ & $0.035(9)^{*}$ & \\
\hline O5 & $0.373(2)$ & $0.7679(18)$ & $0.3239(5)$ & $0.022(7)^{\star}$ & \\
\hline O6 & $0.137(2)$ & $0.508(2)$ & $0.3539(5)$ & $0.031(8)^{*}$ & \\
\hline O7 & 0 & $1.126(2)$ & $0.4074(6)$ & $0.009(8)^{*}$ & \\
\hline O8 & $0.233(2)$ & $0.433(2)$ & $0.4631(5)$ & $0.032(8)^{*}$ & \\
\hline O9 & $0.130(3)$ & $0.244(3)$ & $0.4650(7)$ & $0.060(12)^{\star}$ & \\
\hline O10 & 0.5 & $0.887(3)$ & $0.2968(8)$ & $0.036(12)^{*}$ & \\
\hline O11 & $0.207(2)$ & $1.1602(19)$ & $0.2773(5)$ & $0.027(7)^{*}$ & \\
\hline O12 & $0.269(2)$ & $0.580(2)$ & $0.3219(5)$ & $0.032(8)^{*}$ & \\
\hline O13 & $0.2095(19)$ & $0.6321(17)$ & $0.4446(4)$ & $0.012(6)^{*}$ & \\
\hline O14 & 0 & $0.431(3)$ & $0.4618(9)$ & $0.043(13)^{*}$ & \\
\hline O15 & $0.271(3)$ & $1.455(3)$ & 0.25 & $0.039(13)^{*}$ & \\
\hline O16 & $0.1144(19)$ & $0.4693(18)$ & $0.4202(5)$ & $0.018(7)^{*}$ & \\
\hline O17 & $0.366(2)$ & $0.500(2)$ & $0.4291(5)$ & $0.025(7)^{*}$ & \\
\hline O18 & $0.267(2)$ & $0.4101(19)$ & $0.3871(5)$ & $0.025(7)^{*}$ & \\
\hline O19 & $0.373(2)$ & $0.296(2)$ & $0.4683(5)$ & $0.031(8)^{*}$ & \\
\hline O20 & $0.356(2)$ & $1.025(2)$ & $0.2849(5)$ & $0.034(8)^{*}$ & \\
\hline O21 & $0.366(2)$ & $0.757(2)$ & $0.3900(5)$ & $0.033(8)^{*}$ & \\
\hline $\mathrm{O} 22$ & $0.102(2)$ & $0.985(2)$ & $0.2871(6)$ & $0.044(9)^{*}$ & \\
\hline $\mathrm{O} 23$ & $0.248(3)$ & $0.817(3)$ & $0.4279(7)$ & $0.060(12)^{*}$ & \\
\hline $\mathrm{O} 24$ & 0 & $-0.009(3)$ & $0.4648(8)$ & $0.036(12)^{*}$ & \\
\hline O25 & $0.103(3)$ & $1.309(3)$ & 0.25 & $0.022(10)^{*}$ & \\
\hline $\mathrm{O} 26$ & $0.127(2)$ & $0.7205(19)$ & $0.3123(5)$ & $0.022(7)^{*}$ & \\
\hline $\mathrm{O} 27$ & 0.5 & $0.171(3)$ & $0.4920(8)$ & $0.040(13)^{*}$ & \\
\hline $\mathrm{O} 28$ & 0 & $0.391(3)$ & $0.3769(8)$ & $0.036(12)^{*}$ & \\
\hline O29 & $0.231(2)$ & $0.696(2)$ & $0.3570(5)$ & $0.034(9)^{*}$ & \\
\hline O30 & $0.387(2)$ & $0.552(2)$ & $0.3610(5)$ & $0.030(8)^{*}$ & \\
\hline O31 & $0.235(2)$ & $0.658(2)$ & $0.4953(6)$ & $0.044(10)^{*}$ & \\
\hline O32 & $0.2959(19)$ & $0.3951(17)$ & $0.3335(4)$ & $0.013(6)^{*}$ & \\
\hline O33 & 0.5 & $1.209(3)$ & $0.3523(8)$ & $0.041(13)^{*}$ & \\
\hline O34 & 0 & $1.098(5)$ & $0.3169(12)$ & $0.02(2)^{*}$ & $0.60(10)$ \\
\hline O35 & $0.354(3)$ & $1.255(2)$ & 0.25 & $0.014(9)^{*}$ & \\
\hline O36 & $0.110(2)$ & $0.746(2)$ & $0.3976(6)$ & $0.036(9)^{*}$ & \\
\hline O37 & $0.105(4)$ & 0.5 & 0.5 & $0.048(14)^{*}$ & \\
\hline O38 & 0.5 & $1.398(3)$ & $0.3312(8)$ & $0.034(12)^{*}$ & \\
\hline O39 & 0 & $0.845(3)$ & $0.2155(8)$ & $0.038(13)^{*}$ & \\
\hline O40 & 0 & $1.094(4)$ & 0.25 & $0.038(18)^{*}$ & \\
\hline O41 & $0.357(4)$ & 0.5 & 0.5 & $0.058(16)^{*}$ & \\
\hline $\mathrm{O} 42$ & 0 & $0.912(3)$ & $0.3868(9)$ & $0.049(15)^{*}$ & \\
\hline
\end{tabular}

bic, $a=14.1233(8) \AA, b=13.8196(9) \AA, c=55.7953(12)$ $\AA, V=10890.0(10) \AA^{3}$, and $Z=8$. Integration of the diffraction data, including corrections for background, polarization and Lorentz effects, were carried out with the CrysAlis RED program (Rigaku 2019). A gaussian absorption correction using refined crystal shape (using X-SHAPE program) was applied to data in the Jana2006 software, optimized by spherical harmonics (Petříček et al. 2014). Crystallographic data and experimental details are given in Table 1. The structure of wölsendorfite was solved independently from the previous determination utilizing the charge-flipping algorithm of the SHELXT program (Sheldrick 2015). Therefore, also the atom numbering scheme is distinct from that given by Burns (1999). Structure refinement was done using the software Jana2006 with the full-matrix least-squares refinement based on $F^{2}$. The structure refinement confirmed the choice of the $C$ centered orthorhombic cell and the space group $\mathrm{Cmcm}$. The structure solution revealed positions for all U-atoms within the structure sheet and nearly all of the $\mathrm{Pb}$ atoms in the interlayer (except for those only low-populated); the sheet's completion required the localization of $\mathrm{O}$ atoms from the difference Fourier maps. Nevertheless, despite the data quality, localization was straightforward. The final structure refinement returned higher but still satisfactory $R$-values, $R=10.84 \%$ and $w R=19.64 \%$ for 3185 unique observed reflections, fulfilling the criterion for observed intensities $I_{\text {obs }}>3 \sigma(I)$. We have to keep in mind the number of heavy atoms in, nevertheless, the large unit cell, leading to the immense absorption for X-rays ( $\mu=60.77$ $\mathrm{mm}^{-1}$ ) and consequent problems with the low intensities and proportionally large experimental errors. The weak intensities and poorer absorption correction are also the reason for both weakly negative (U1 and $\mathrm{U} 2$ ) and significantly small but positive (for instance, U3, O1, O2) values of equivalent atomic displacement parameters; the final fit thus treated them equally. It was not possible to discern reliably the amount of possibly entering $\mathrm{Ba}$ to the certain atomic site. Nevertheless, based on further crystal-chemical considerations (see below), the conclusion made is that currently studied wölsendorfite is possibly Ba-free. Final atom coordinates are given in Table 2, selected interatomic distances in Table 3, and the results of the bond-valence analysis in Table 4. Crystallographic data (CIF) are available as supplementary material online.

In order to evaluate the structural complexity of wölsendorfite, the information-based approach developed by Krivovichev $(2012,2013,2014,2016)$ and recently used for determination of structural complexity of $U^{6+}$ oxysalts elsewhere (e.g., Gurzhiy, Plášil 2019; Gurzhiy et al. 2019; Kornyakov et al. 2020; Plášil 2018a) has been used. The structural complexity is quantitatively estimated as a Shannon information content (in bits) per atom $\left(I_{G}\right)$ and per unit cell $\left(I_{\mathrm{G}, \text { total }}\right)$.

\section{Refined crystal structure of wölsendorfite}

The large unit cell of wölsendorfite (Fig. 1) contains eight distinct $\mathrm{U}$ sites, further on, it contains eight $\mathrm{Pb}$ and thirty-two $\mathrm{O}$ sites (plus $\mathrm{H}$-sites, which, nevertheless, have not been revealed by the current refinement).

In wölsendorfite, all $U$ sites are occupied by $U^{6+}$, according to the bond-valence analysis (Tab. 4). The $U^{6+}$ cation is strongly bonded by the triple bonds to two $\mathrm{O}$ atoms, forming nearly linear $\left(\mathrm{UO}_{2}\right)^{2+}$ uranyl ions. The $\mathrm{U}-$ $\mathrm{O}_{\mathrm{Ur}}$ bond-lengths are $\sim 1.8 \AA$, except of $\mathrm{U} 2$ and $\mathrm{U} 4$ sites (Tab. 3); however, it is most probably due to poorer absorption correction. Despite that, all refined bond-lengths 
lie within the range of bond-lengths obtained from the weIl-refined structures (Lussier et al. 2016). The uranyl ions are further coordinated by four or five equatorial ligands, resulting in Ur $\Phi_{4}$ square bipyramids and Ur $\Phi_{5}$ pentagonal bipyramids, respectively (where $\Phi$ denotes an unspecified ligand). Uranyl ion at the U3 and U7 sites is coordinated by four $\mathrm{O}$ atoms; the remaining uranyl ions are each coordinated by five anions (Tab. 3 and 4).

As mentioned by Burns (1999), one of the $U^{6+}$-coordination polyhedrons contains $\mathrm{U}^{6+}-(\mathrm{OH})_{\mathrm{eq}}$ separation peculiarly long. In the case of wölsendorfite studied by Burns (1999) it was $3.06 \AA$. The conclusion made that it goes about the weak bond, considerably longer than most $\mathrm{U}^{6+}-\Phi_{\mathrm{eq}}$ bonds. Moreover, a similar finding was made by Pagoaga et al. (1987) (3.02 $\AA$ ) and also by Finch et al. (2006) (3.097 $\AA$ ) for the structure of billietite. The peculiarly long $\mathrm{U}-\mathrm{OH}$ bond is confirmed by the current study: the U8 polyhedra contains U8-O32 bond, $3.026 \AA$ long (Tab. 3 , contributing $0.13 v u$ to the central U8 atom (Tab. 5).

Table 3 Interatomic distances among $U^{6+}$ polyhedra (in $\AA$ ) in the structure of wölsendorfite.

\begin{tabular}{|c|c|c|c|}
\hline U1-O1 & $2.25(3)$ & U2-08 & $2.25(3)$ \\
\hline U1-08 & $2.26(3)$ & U2-09 & $1.74(4)$ \\
\hline U1-013 & $2.35(3)$ & U2-O13i & $2.36(3)$ \\
\hline U1-016 & $1.82(3)$ & U2-O19 & $1.78(3)$ \\
\hline U1-017 & $1.80(3)$ & U2-O23i & $2.26(4)$ \\
\hline U1-018 & $2.37(3)$ & U2-O31ii & $2.34(3)$ \\
\hline U1-O23i & $2.33(4)$ & U2-O31'i & $2.24(3)$ \\
\hline$<U 1-\mathrm{O}_{U r}>$ & 1.82 & $<\mathrm{U} 2-\mathrm{O}_{U r}>$ & 1.76 \\
\hline$<\mathrm{U} 1-\mathrm{O}_{\mathrm{eq}}>$ & 2.31 & $<\mathrm{U} 2-\mathrm{O}_{e q}>$ & 2.29 \\
\hline U3-01 & $2.17(3)$ & U4-O4iv & $2.30(3)$ \\
\hline U3-O18iii & $2.19(3)$ & U4-O4 & $2.30(3)$ \\
\hline U3-O21 & $1.80(3)$ & U4-O11 & $2.30(3)$ \\
\hline U3-O23 & $2.12(4)$ & U4-O11v & $2.30(3)$ \\
\hline U3-O29 & $2.18(3)$ & U4-015 & $2.45(4)$ \\
\hline U3-036 & $1.84(3)$ & U4-O25 & $1.87(4)$ \\
\hline$<U 3-\mathrm{O}_{U r}>$ & 1.82 & U4-O35 & $1.76(4)$ \\
\hline \multirow{2}{*}{$<\mathrm{U} 3-\mathrm{O}_{\text {eq }}>$} & 2.17 & $<U 4-\mathrm{O}_{U r}>$ & 1.81 \\
\hline & & $<\mathrm{U} 4-\mathrm{O}_{e q}>$ & 2.33 \\
\hline U5-O1 & $2.29(2)$ & U6-O4 & $2.21(3)$ \\
\hline U5-O6 & $1.78(3)$ & U6-O5 & $1.78(3)$ \\
\hline U5-012 & $2.18(3)$ & U6-O11' & $2.59(3)$ \\
\hline U5-O18 & $2.28(3)$ & U6-012 & $2.30(3)$ \\
\hline U5-O29 & $2.36(3)$ & U6-O26 & $1.82(3)$ \\
\hline U5-O30 & $1.83(3)$ & U6-O29 & $2.33(3)$ \\
\hline U5-O32 & $2.37(3)$ & U6-O32iii & $2.37(3)$ \\
\hline$<U 5-O_{U r}>$ & 1.82 & $<\mathrm{U} 6-\mathrm{O}_{U r}>$ & 1.81 \\
\hline$<\mathrm{U} 5-\mathrm{O}_{\mathrm{eq}}>$ & 2.30 & $<\mathrm{U} 6-\mathrm{O}_{e q}>$ & 2.36 \\
\hline U7-08 & $2.26(3)$ & U8-O4 & $2.18(3)$ \\
\hline U7-O8 & $2.26(3)$ & U8-011 & $2.24(3)$ \\
\hline U7-031 & $2.20(3)$ & U8-012iii & $2.20(3)$ \\
\hline U7-O31ii & $2.20(3)$ & U8-015 vi & $2.188(13)$ \\
\hline U7-037 & $1.81(6)$ & U8-O20 & $1.78(3)$ \\
\hline U7-041 & $1.74(6)$ & U8-O22 & $1.85(3)$ \\
\hline$<U 7-\mathrm{O}_{U r}>$ & 1.78 & U8-O32iii & $3.02(3)$ \\
\hline \multirow[t]{2}{*}{$<U 7-\mathrm{O}_{\text {eq }}>$} & 2.23 & $<\mathrm{U} 8-\mathrm{O}_{U r}>$ & 1.82 \\
\hline & & $<\mathrm{U} 8-\mathrm{O}_{e q}>$ & 2.37 \\
\hline
\end{tabular}

Symmetry codes: (i) $-x+1 / 2, y-1 / 2, z$; (ii) $x,-y+1,-z+1$; (iii) $-x+1 / 2, y+1 / 2, z$; (iv) $-x+1 / 2, y+1 / 2,-z+1 / 2$; (v) $x, y$, $-z+1 / 2 ;$ (vi) $-x+1 / 2, y-1 / 2,-z+1 / 2$.
Table 4 Interatomic distances among $\mathrm{Pb}^{2+}$ polyhedra (in $\AA$ ) in the structure of wölsendorfite.

\begin{tabular}{|c|c|c|c|}
\hline Pb1-O5 vii & $2.94(3)$ & $\mathrm{Pb} 2-07^{\text {ix }}$ & $2.96(3)$ \\
\hline Pb1-O5 & $2.94(3)$ & Pb2-O9 & $3.19(4)$ \\
\hline Pb1-O7 & $2.72(3)$ & $\mathrm{Pb} 2-09^{x}$ & $3.19(4)$ \\
\hline $\mathrm{Pb} 1-\mathrm{O} 21^{\text {vii }}$ & $2.57(3)$ & $\mathrm{Pb} 2-\mathrm{O} 14$ & $2.56(4)$ \\
\hline $\mathrm{Pb} 1-\mathrm{O} 21^{\mathrm{iii}}$ & $2.57(3)$ & Pb2-O16 & $2.51(3)$ \\
\hline Pb1-O28viii & $2.76(4)$ & $\mathrm{Pb} 2-\mathrm{O} 16^{\mathrm{x}}$ & $2.51(3)$ \\
\hline Pb1-O30vii & $2.60(3)$ & $\mathrm{Pb} 2-\mathrm{O} 21^{\mathrm{xi}}$ & $2.84(3)$ \\
\hline Pb1-O30iii & $2.60(3)$ & $\mathrm{Pb} 2-\mathrm{O} 21^{\mathrm{i}}$ & $2.84(3)$ \\
\hline Pb1-O34 & $2.90(6)$ & Pb2-O28 & $2.73(4)$ \\
\hline$<\mathrm{Pb} 1-\mathrm{O}>$ & 2.73 & $<\mathrm{Pb} 2-\mathrm{O}>$ & 2.81 \\
\hline Pb3-O9 & $2.99(4)$ & $\mathrm{Pb} 4-\mathrm{O} 2$ & $2.53(3)$ \\
\hline Pb3-O9x & $2.99(4)$ & $\mathrm{Pb} 4-\mathrm{O6}^{\mathrm{xv}}$ & $3.02(3)$ \\
\hline Pb3-O19xii & $2.65(3)$ & Pb4-O6 & $3.02(3)$ \\
\hline Pb3-O19xiii & $2.65(3)$ & $\mathrm{Pb} 4-\mathrm{O} 10$ & $2.98(4)$ \\
\hline Pb3-O24 & $2.90(4)$ & Pb4-O20 & $2.85(3)$ \\
\hline Pb3-O24 & $2.74(4)$ & $\mathrm{Pb} 4-\mathrm{O} 20^{\mathrm{xvi}}$ & $2.85(3)$ \\
\hline Pb3-O27xii & $2.57(4)$ & $\mathrm{Pb} 4-\mathrm{O} 26^{\mathrm{xv}}$ & $2.60(3)$ \\
\hline Pb3-O41 & $2.86(4)$ & Pb4-O26iii & $2.60(3)$ \\
\hline Pb3-O41 xiii & $2.86(4)$ & Pb4-O33 & $2.59(4)$ \\
\hline <Pb3-O> & 2.80 & $<\mathrm{Pb} 4-\mathrm{O}>$ & 2.78 \\
\hline $\mathrm{Pb} 5-\mathrm{O} 3$ & $2.61(3)$ & $\mathrm{Pb} 6-\mathrm{O} 2$ & $3.02(3)$ \\
\hline Pb5-O17vii & $3.13(3)$ & $\mathrm{Pb} 6-\mathrm{O} 2^{\mathrm{xvii}}$ & $3.02(3)$ \\
\hline Pb5-O17 & $3.13(3)$ & Pb6-O10 & $2.81(4)$ \\
\hline Pb5-O19vii & $3.10(3)$ & Pb6-O10 xvii & $2.81(4)$ \\
\hline Pb5-O19iii & $3.10(3)$ & Pb6-O20 & $2.95(3)$ \\
\hline Pb5-O24 viii & $3.30(4)$ & Pb6-O20xvii & $2.95(3)$ \\
\hline Pb5-O36 & $2.36(3)$ & $\mathrm{Pb} 6-\mathrm{O} 20^{\vee}$ & $2.95(3)$ \\
\hline Pb5-O36 & $2.36(3)$ & $\mathrm{Pb} 6-\mathrm{O} 20^{\mathrm{xvi}}$ & $2.95(3)$ \\
\hline Pb5-O42 & $2.40(5)$ & $\mathrm{Pb} 6-\mathrm{O} 25^{\mathrm{xviii}}$ & $2.57(4)$ \\
\hline \multirow[t]{2}{*}{$<\mathrm{Pb} 5-\mathrm{O}\rangle$} & 2.83 & $\mathrm{~Pb} 6-\mathrm{O} 25^{\mathrm{vi}}$ & $2.57(4)$ \\
\hline & & $<\mathrm{Pb} 6-\mathrm{O}>$ & 2.84 \\
\hline $\mathrm{Pb} 7 / \mathrm{Ca} 7-\mathrm{O}^{\mathrm{xii}}$ & $3.28(3)$ & Pb8-01 & $3.42(3)$ \\
\hline Pb7/Ca7-O5 & $3.28(3)$ & $\mathrm{Pb} 8-01^{x}$ & $3.42(3)$ \\
\hline $\mathrm{Pb} 7 / \mathrm{Ca} 7-010^{\mathrm{xi}}$ & $3.14(4)$ & Pb8-O3 & $2.83(4)$ \\
\hline Pb7/Ca7-O11 & $2.93(3)$ & Pb8-06 & $3.15(3)$ \\
\hline $\mathrm{Pb} 7 / \mathrm{Ca} 7-011^{x}$ & $2.93(3)$ & Pb8-O6 & $3.15(3)$ \\
\hline Pb7 /Ca7-O22 & $2.93(3)$ & Pb8-016 & $2.87(3)$ \\
\hline $\mathrm{Pb} 7 / \mathrm{Ca} 7-022^{\mathrm{x}}$ & $2.93(3)$ & Pb8-016 & $2.87(3)$ \\
\hline $\mathrm{Pb} 7 / \mathrm{Ca} 7-\mathrm{O} 25$ & $2.99(3)$ & Pb8-O28 & $3.00(4)$ \\
\hline $\mathrm{Pb} 7 / \mathrm{Ca} 7-025^{\mathrm{xix}}$ & $2.99(3)$ & Pb8-O33 & $2.70(5)$ \\
\hline Pb7/ Ca7-O34 & $2.21(6)$ & Pb8-O36 & $2.57(3)$ \\
\hline Pb7/ Ca7-O40 & $2.03(3)$ & $\mathrm{Pb} 8-036^{x}$ & $2.57(3)$ \\
\hline$<\mathrm{Pb} 7 / \mathrm{Ca} 7-\mathrm{O}>$ & 2.88 & $<\mathrm{Pb} 8-\mathrm{O}>$ & 2.95 \\
\hline $\mathrm{Pb9-O35^{ \textrm {xi } }}$ & $3.28(3)$ & & \\
\hline Pb9-O35vi & $3.28(3)$ & & \\
\hline Pb9-O39 & $2.33(4)$ & & \\
\hline Pb9-O39xix & $2.33(4)$ & & \\
\hline Pb9-O40 & $2.13(6)$ & & \\
\hline Pb9-O22 & $2.60(3)$ & & \\
\hline $\mathrm{Pb9-015^{ \textrm {xv } }}$ & $3.24(4)$ & & \\
\hline$<\mathrm{Pb9}-\mathrm{O}>$ & 2.74 & & \\
\hline \multicolumn{4}{|c|}{ 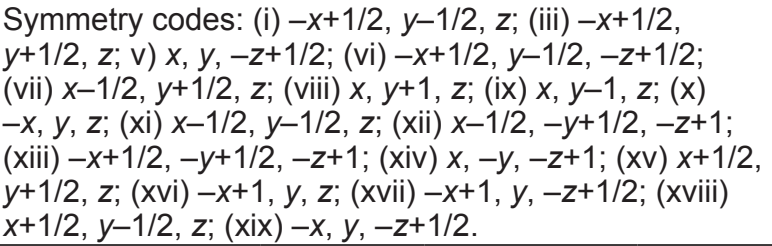 } \\
\hline
\end{tabular}


There are eight symmetrically distinct $\mathrm{Pb}$-sites in the interlayer (Fig. 2). The polyhedral geometries (Tab. 4) and bond-valence sums incident upon those sites (Tab. 5) are consistent with all $\mathrm{Pb}$ present as $\mathrm{Pb}^{2+}$, as is the case for all known $\mathrm{Pb}$-containing uranyl-oxide hydroxy -hydrate minerals (Plášil 2018). According to site-scattering refinement results, some of the sites ( $\mathrm{Pb} 7$ and $\mathrm{Pb} 8)$ are considerably low-populated, $<0.5$. Unlike the conclusion made by Burns (1999), one of the sites in the crystal studied by him, the Pb8 site is a mix-site containing both $\mathrm{Pb}$ and $\mathrm{Ba}$, wölsendorfite studied by the current study probably does not contain $\mathrm{Ba}$ at all, or only marginally. The argument of Burns (1999) was, besides the refinement, geometrical: conforming the larger average $\mathrm{Pb} 8-\Phi$ bond-length with the larger ionic radius of $\mathrm{Ba}^{2+}$ over $\mathrm{Pb}^{2+}$ (Shannon 1976). For instance, ${ }^{[10]} \mathrm{Pb}^{2+}$ has ionic radius of $1.4 \AA$, while ${ }^{[10]} \mathrm{Ba}^{2+}$ has $1.5 \AA$. The comparison of corresponding Voronoi-Dirichlet polyhedral (VDP) volumes for the $\mathrm{Pb}^{2+}$-coordination polyhedra in wölsendorfite studied by Burns (1999) clearly shows that Pb8/Ba8 polyhedron is considerably larger $\left(22.77 \AA^{3}\right)$ than the average volume, $V_{\mathrm{VDP}}=17.06 \AA^{3}$, of the remaining polyhedra. Any similar larger polyhedra are not present in the currently studied structure (Tab. 6). Therefore the conclusion is that the currently studied wölsendorfite is Ba-free. Moreover, based on the smaller volume of the $\mathrm{Pb} 7$ and the fact that the studied crystal comes in the Ca-rich association, this site has been treated as a mixed $\mathrm{Pb} / \mathrm{Ca}$ site (Tab. 2 and 5). As all $\mathrm{Pb}$ polyhedra in the interlayer of wölsendorfite (Fig. 2) are fairly irregular, and some are distinctly one-sided, it suggests that the $\mathrm{Pb}^{2+}$ cations are lone-pair stereoactive.
In contrast to the structure given by Burns (1999) there are some substantial differences obtained from the current refinement. It has revealed two additional $\mathrm{O}$ sites that belong to $\mathrm{H}_{2} \mathrm{O}$ and different proportions of the $\mathrm{O}$ and $\mathrm{OH}$ within the sheet. The sum of the $\mathrm{H}_{2} \mathrm{O}$, based on the refined occupancies of those sites that were partially occupied (based on the high $U_{\text {iso }}$ values at first), is 12.85 $\mathrm{H}_{2} \mathrm{O}$ per unit cell, for $Z=8$. Based on the bond-valence analysis, it is likely that there could be $5 \mathrm{OH}$ and $18 \mathrm{O}$ within the layer, giving a net charge of -13 , in contrast to the net charge -14 by Burns (1999). One of the $\mathrm{O}$ atoms, $\mathrm{O} 40$, which is a ligand of $\mathrm{Pb} 7 / \mathrm{Ca} 7$ and $\mathrm{Pb} 9$ polyhedra, seems to be $\mathrm{O}^{2-}$ (sum of $\mathrm{BV} \sim 1.6 \mathrm{vu}$ ), most probably accepting one additional weak $\mathrm{H}$-bond to meet its $\mathrm{BV}$ requirements. Considering this, there is an additional 0.50 in the interlayer (O40 had a multiplicity of 4$)$. The formula for the wölsendorfite crystal studied can be written as $\mathrm{Pb}_{6.07} \mathrm{Ca}_{0.68}\left[\left(\mathrm{UO}_{2}\right)_{14} \mathrm{O}_{18}(\mathrm{OH})_{5}\right] \mathrm{O}_{0.5}\left(\mathrm{H}_{2} \mathrm{O}\right)_{12.6}$, with $\mathrm{Z}=8, D_{\text {calc. }}$ $=6.919 \mathrm{~g} \mathrm{~cm}^{-3}$ (including theoretical $30.2 \mathrm{H}$ atoms). This formula has a net charge of -0.50 , indicating that there can be some $\mathrm{O} \leftrightarrow \mathrm{OH}$ substitution within the structure sheets. Another possibility is that $\mathrm{O} 40$ is the $\mathrm{OH}$ group instead (the shorter $\mathrm{Pb} 7-\mathrm{O} 40$ would be an artifact of the poorer fit). The corresponding formula is then $\mathrm{Pb}_{6.07} \mathrm{Ca}_{0.68}\left[\left(\mathrm{UO}_{2}\right)_{14}\right.$ $\mathrm{O}_{18}(\mathrm{OH})_{5} \mathrm{OH}_{0.5}\left(\mathrm{H}_{2} \mathrm{O}\right)_{12.6}$, which is electroneutral.

\section{Complexity of wölsendorfite in comparison with other UOHs}

In general, some of UOHs are among the very complex minerals, considering the categories established by Krivovichev (2013). So far, the most complex UOH mineral (Tab. 7) is vandendriesscheite, $\mathrm{Pb}_{1.5}\left[\left(\mathrm{UO}_{2}\right)_{10} \mathrm{O}_{6}(\mathrm{OH})_{11}\right]$

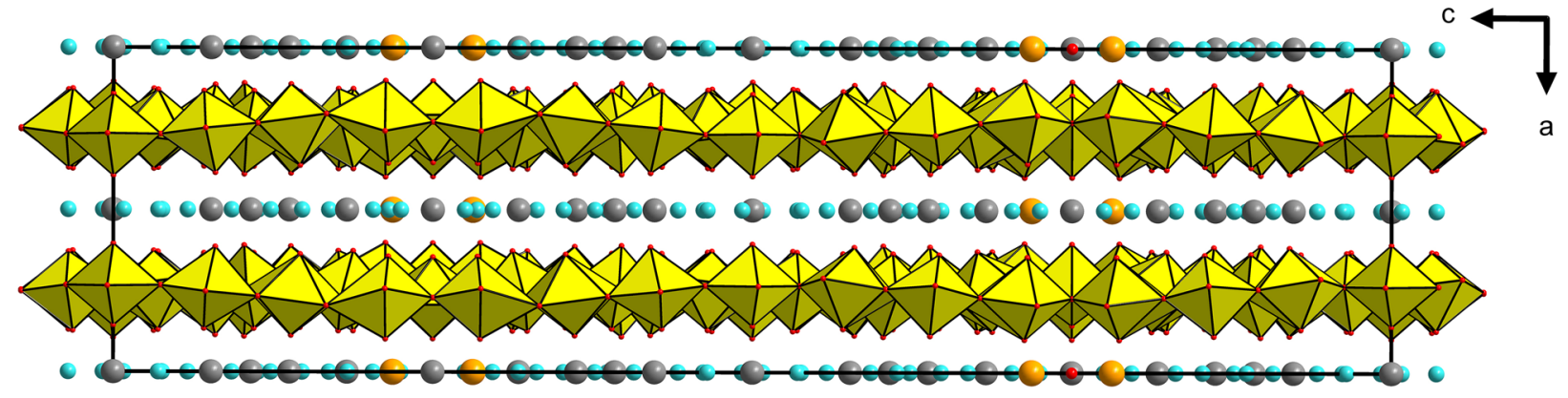

Fig. 1 Crystal structure of wölsendorfite, view down [010]. Uranyl polyhedra are yellow, O atoms are represented by red circles, $\mathrm{H}_{2} \mathrm{O}$ groups as azure circles, $\mathrm{Pb}^{2+}$ grey and $\mathrm{Ca}^{2+}$-populated sites orange. Unit-cell edges are outlined as black-solid lines.

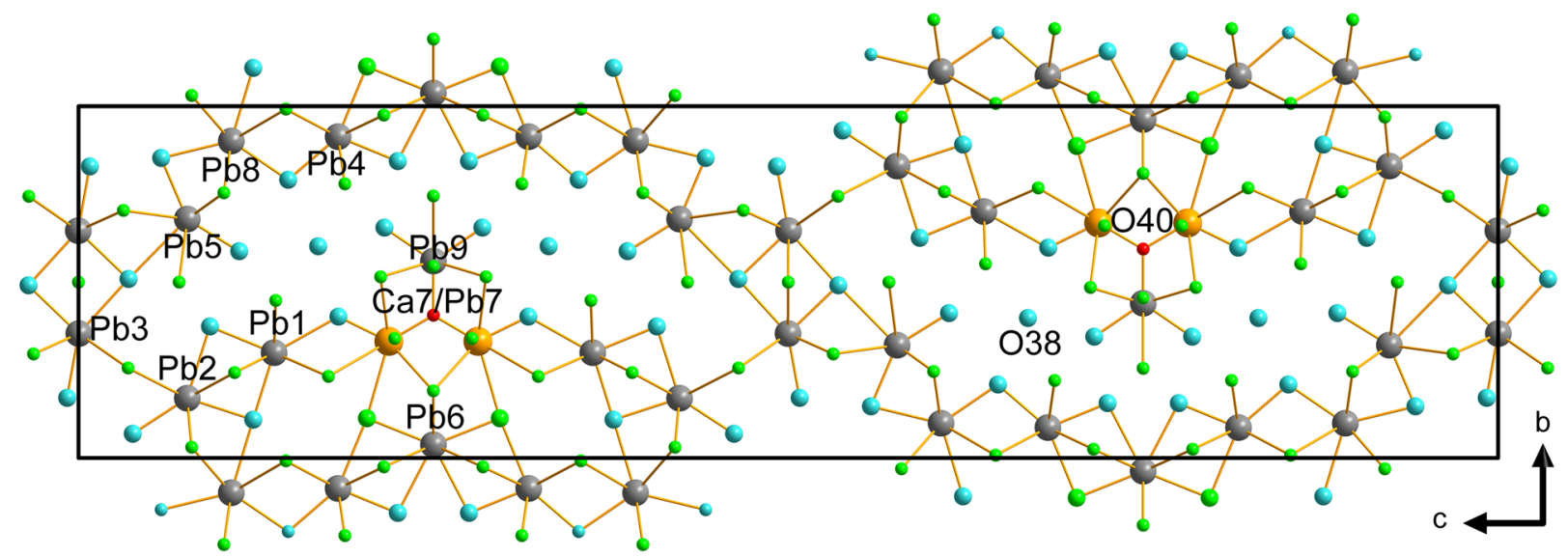

Fig. 2 Interlayer complex in the studied wölsendorfite, view down [100]. $\mathrm{Pb}^{2+}$ sites are in grey and $\mathrm{Ca}^{2+}$-populated sites in orange color; $\mathrm{O}$ sites that are ligands of the U-polyhedra are displayed as green spheres; $\mathrm{H}_{2} \mathrm{O}$ groups are azure. Unit-cell edges are outlined as black-solid lines. 
$\left(\mathrm{H}_{2} \mathrm{O}\right)_{11}$ (Burns 1997). This mineral appears relatively soon in the alteration sequence after uraninite (Finch, Ewing 1992; Plášil 2018) and is characteristic for the presence of $\mathrm{Pb}^{2+}$, usually of the radiogenic origin, derived from weathered pitchblende. The second most complex mineral is gauthierite, $\mathrm{KPb}\left[\left(\mathrm{UO}_{2}\right)_{7} \mathrm{O}_{5}(\mathrm{OH})_{7}\right]\left(\mathrm{H}_{2} \mathrm{O}\right)_{8}$ (Olds et al. 2017a), which seems to appear relatively soon in the sequence after vandendriesscheite. Its structure is based on its own topology, called gauthierite topology, which resembles vandendriesscheite, but it has a shorter sequence. The structure contains additional cation, $\mathrm{K}^{+}$, but on the other hand, has a lower molar proportion of $\mathrm{H}_{2} \mathrm{O}$. The third most complex $\mathrm{UOH}$ has to be newly considered wöl- sendorfite. This study revealed additional $\mathrm{H}_{2} \mathrm{O}$ sites, and both richetite and schoepite that had been considered in the past as far more complex turned out to be less-complex actually as they have been structurally revisited (Plášil 2017, 2018). For comparison, the most complex mineral in Nature is the uranyl carbonate ewingite (Olds et al. 2017b), $\mathrm{Mg}_{8} \mathrm{Ca}_{8}\left(\mathrm{UO}_{2}\right)_{24}\left(\mathrm{CO}_{3}\right)_{30} \mathrm{O}_{4}(\mathrm{OH})_{12}\left(\mathrm{H}_{2} \mathrm{O}\right)_{138}$. This mineral is not, however, based on sheets of uranyl polyhedra, like UOHs, but it contains nano-sized metal-oxo clusters that, so far, have no close chemical or topological analogs in synthetic chemistry. The information content of 23477.51 bits/cell (including $\mathrm{H}$ atoms) makes it the most complex mineral (Krivovichev 2020).

Table 5 Bond-valence analysis for the structure of wölsendorfite.

\begin{tabular}{|c|c|c|c|c|c|c|c|c|c|c|c|c|c|c|c|c|c|c|c|}
\hline & U1 & U2 & U3 & U4 & U5 & U6 & U7 & U8 & $\mathrm{Pb} 1$ & $\mathrm{~Pb} 2$ & Pb3 & $\mathrm{Pb} 4$ & Pb5 & Pb6 & $\begin{array}{l}\mathrm{Pb} 7 / \\
\mathrm{Ca} 7\end{array}$ & $\mathrm{Pb8}$ & Pb9 & $\Sigma \mathrm{BV}$ & $\begin{array}{c}\text { Assign- } \\
\text { ment }\end{array}$ \\
\hline 01 & 0.65 & & 0.77 & & 0.60 & & & & & & & & & & & $0.05^{\times 2 \downarrow}$ & & 2.06 & $\mathrm{O}$ \\
\hline $\mathrm{O} 2$ & & & & & & & & & & & & 0.32 & & $0.11^{\times 2 \downarrow}$ & & & & 0.27 & $\mathrm{H}_{2} \mathrm{O}$ \\
\hline $\mathrm{O} 3$ & & & & & & & & & & & & & 0.27 & & & 0.16 & & 0.43 & $\mathrm{H}_{2}^{2} \mathrm{O}$ \\
\hline $\mathrm{O} 4$ & & & & $0.59^{\times 2 \downarrow}$ & & 0.71 & & 0.75 & & & & & & & & & & 2.04 & $\mathrm{O}^{2}$ \\
\hline $\mathrm{O} 5$ & & & & & & 1.75 & & & $0.13^{\times 2 \downarrow}$ & & & & & & $0.05^{\times 2 \downarrow}$ & & & 1.93 & 0 \\
\hline 06 & & & & & 1.75 & & & & & & & $0.11^{\times 2 \downarrow}$ & & & & $0.08^{\times 2 \downarrow}$ & & 1.94 & 0 \\
\hline O7 & & & & & & & & & 0.21 & 0.12 & & & & & & & & 0.33 & $\mathrm{H}_{2} \mathrm{O}$ \\
\hline O8 & 0.64 & 0.65 & & & & & $0.64^{\times 2 \downarrow}$ & & & & & & & & & & & 1.92 & $\mathrm{O}$ \\
\hline 09 & & 1.91 & & & & & & & & $0.07^{\times 2 \downarrow}$ & $0.12^{\times 2 \downarrow}$ & & & & & & & 2.10 & 0 \\
\hline 010 & & & & & & & & & & & & 0.12 & & $0.17^{\times 2 \downarrow}$ & 0.06 & & & 0.34 & $\mathrm{H} 2 \mathrm{O}$ \\
\hline 011 & & & & $0.59^{\times 2 \downarrow}$ & & 0.32 & & 0.66 & & & & & & & $0.10^{\times 2 \downarrow}$ & & & 1.66 & 0 \\
\hline 012 & & & & & 0.75 & 0.58 & & 0.72 & & & & & & & & & & 2.06 & 0 \\
\hline 013 & 0.53 & 0.51 & & & & & & & & & & & & & & & & 1.04 & $\mathrm{OH}$ \\
\hline 014 & & & & & & & & & & 0.30 & & & & & & & & 0.30 & $\mathrm{H}_{2} \mathrm{O}$ \\
\hline 015 & & & & 0.43 & & & & 0.74 & & & & & & & & & 0.07 & 1.23 & $\mathrm{OH}$ \\
\hline 016 & 1.61 & & & & & & & & & $0.34^{\times 2 \downarrow}$ & & & & & & $0.15^{\times 2 \downarrow}$ & & 2.10 & $\mathrm{O}$ \\
\hline 017 & 1.68 & & & & & & & & & & & & $0.08^{\times 2 \downarrow}$ & & & & & 1.77 & $\mathrm{O}$ \\
\hline 018 & 0.50 & & 0.74 & & 0.61 & & & & & & & & & & & & & 1.85 & 0 \\
\hline 019 & & 1.75 & & & & & & & & & $0.25^{\times 2 \downarrow}$ & & $0.09^{\times 2 \downarrow}$ & & & & & 2.09 & 0 \\
\hline $\mathrm{O} 20$ & & & & & & & & 1.75 & & & & $0.16^{\times 2 \downarrow}$ & & $0.13^{\times 4 \downarrow}$ & & & & 2.16 & 0 \\
\hline $\mathrm{O} 21$ & & & 1.68 & & & & & & $0.30^{\times 2 \downarrow} \mathrm{C}$ & $0.16^{\times 2 \downarrow}$ & & & & & & & & 2.14 & 0 \\
\hline $\mathrm{O} 22$ & & & & & & & & 1.51 & & & & & & & $0.10^{\times 2 \downarrow}$ & & 0.28 & 1.89 & $\mathrm{O}$ \\
\hline $\mathrm{O} 23$ & 0.55 & 0.64 & 0.86 & & & & & & & & & & & & & & & 2.04 & $\mathrm{O}$ \\
\hline O24 & & & & & & & & & & & $\begin{array}{l}0.14 \\
020\end{array}$ & & 0.06 & & & & & 0.23 & $\mathrm{H}_{2} \mathrm{O}$ \\
\hline $\mathrm{O} 25$ & & & & 1.45 & & & & & & & & & & $0.30^{\times 2 \downarrow}$ & $0.09^{\times 2 \downarrow}$ & & & 1.83 & 0 \\
\hline $\mathrm{O} 26$ & & & & & & 1.61 & & & & & & $0.28^{\times 2 \downarrow}$ & & & & & & 1.89 & 0 \\
\hline $\mathrm{O} 27$ & & & & & & & & & & & 0.30 & & & & & & & 0.30 & $\mathrm{H}_{2} \mathrm{O}$ \\
\hline O28 & & & & & & & & & 0.19 & 0.21 & & & & & & 0.11 & & 0.51 & $\mathrm{H}_{2} \mathrm{O}$ \\
\hline O29 & & & 0.75 & & 0.51 & 0.55 & & & & & & & & & & & & 1.82 & $\mathrm{O}^{2}$ \\
\hline 030 & & & & & 1.58 & & & & $0.28^{\times 2 \downarrow}$ & & & & & & & & & 1.86 & 0 \\
\hline O31 & & $\begin{array}{l}0.54 \\
0.66\end{array}$ & & & & & $0.72^{\times 2 \downarrow}$ & & & & & & & & & & & 1.32 & 0 \\
\hline O32 & & & & & 0.50 & 0.50 & & 0.13 & & & & & & & & & & 1.14 & $\mathrm{OH}$ \\
\hline 033 & & & & & & & & & & & & 0.28 & & & & 0.22 & & 0.50 & $\mathrm{H}_{2} \mathrm{O}$ \\
\hline O34 & & & & & & & & & 0.14 & & & & & & 0.54 & & & 0.68 & $\mathrm{H}_{2} \mathrm{O}$ \\
\hline 035 & & & & 1.83 & & & & & & & & & & & & & $0.06^{\times 2 \downarrow}$ & 1.89 & $\mathrm{O}^{2}$ \\
\hline 036 & & & 1.55 & & & & & & & & & & $0.48^{\times 2 \downarrow}$ & & & $0.30^{\times 2 \downarrow}$ & & 2.32 & 0 \\
\hline O37 & & & & & & & 1.65 & & & & & & & & & & & 1.65 & 0 \\
\hline 038 & & & & & & & & & & & & & & & & & & 0.00 & $\mathrm{H}_{2} \mathrm{O}$ \\
\hline O39 & & & & & & & & & & & & & & & & & $0.51^{\times 2 \downarrow}$ & 0.51 & $\mathrm{H}_{2} \mathrm{O}$ \\
\hline 040 & & & & & & & & & & & & & & & 0.82 & & 0.80 & 1.63 & 0 \\
\hline 041 & & & & & & & 1.91 & & & & $0.15^{\times 2 \downarrow}$ & & & & & & & 2.06 & 0 \\
\hline 042 & & & & & & & & & & & & & 0.43 & & & & & 0.43 & $\mathrm{H}_{2} \mathrm{O}$ \\
\hline & 6.16 & 6.67 & 6.34 & 6.05 & 6.31 & 6.03 & 6.27 & 6.28 & $1.85^{*}$ & $1.70^{*}$ & $1.59^{*}$ & $1.69^{*}$ & $1.91^{*}$ & $1.43^{*}$ & $2.07^{*}$ & $0.26^{*}$ & $1.99^{*}$ & & \\
\hline
\end{tabular}

All values are given in valence-units $(v u)$; bond-valence parameters taken from Gagné, Hawthorne (2015); *the site occupancies were considered. 
Table 6 Comparison of Voronoi-Dirichlet polyhedra volumes for $\mathrm{Pb}^{2+}-\mathrm{Ca}^{2+}$ and $\mathrm{Ba}^{2+}$-populated polyhedra for wölsendorfite.

\begin{tabular}{|c|c|c|c|c|}
\hline \multirow{2}{*}{\multicolumn{2}{|c|}{$\begin{array}{ll}\text { Mineral } & \text { Reference } \\
\text { wölsendorfite } & \text { this paper }\end{array}$}} & \multirow{2}{*}{$\begin{array}{l}\text { Site } \\
\mathrm{Pb} 1\end{array}$} & \multicolumn{2}{|c|}{$V_{V D P}\left[\AA^{3}\right]$ Occ. of $\mathrm{Ba}^{2+} / \mathrm{Ca}^{2+}$} \\
\hline & & & 16.19 & 0 \\
\hline & & $\mathrm{Pb} 2$ & 17.75 & 0 \\
\hline & & Pb3 & 17.55 & 0 \\
\hline & & $\mathrm{Pb} 4$ & 17.41 & 0 \\
\hline & & $\mathrm{Pb} 5$ & 16.85 & 0 \\
\hline & & $\mathrm{Pb} 6$ & 17.64 & 0 \\
\hline & & $\mathrm{Ca} 7 / \mathrm{Pb} 7$ & 15.92 & 0.68 \\
\hline & & $\mathrm{Pb} 8$ & 17.98 & 0 \\
\hline wölsendorfite & Burns (1999) & $\mathrm{Pb} 1$ & 17.76 & 0 \\
\hline & & $\mathrm{Pb} 2$ & 17.35 & 0 \\
\hline & & Pb3 & 16.97 & 0 \\
\hline & & $\mathrm{Pb} 4$ & 16.97 & 0 \\
\hline & & Pb5 & 17.06 & 0 \\
\hline & & $\mathrm{Pb} 6$ & 18.61 & 0 \\
\hline & & $\mathrm{Pb} 7$ & * & \\
\hline & & $\mathrm{Ba8/Pb8}$ & 22.77 & 0.36 \\
\hline
\end{tabular}

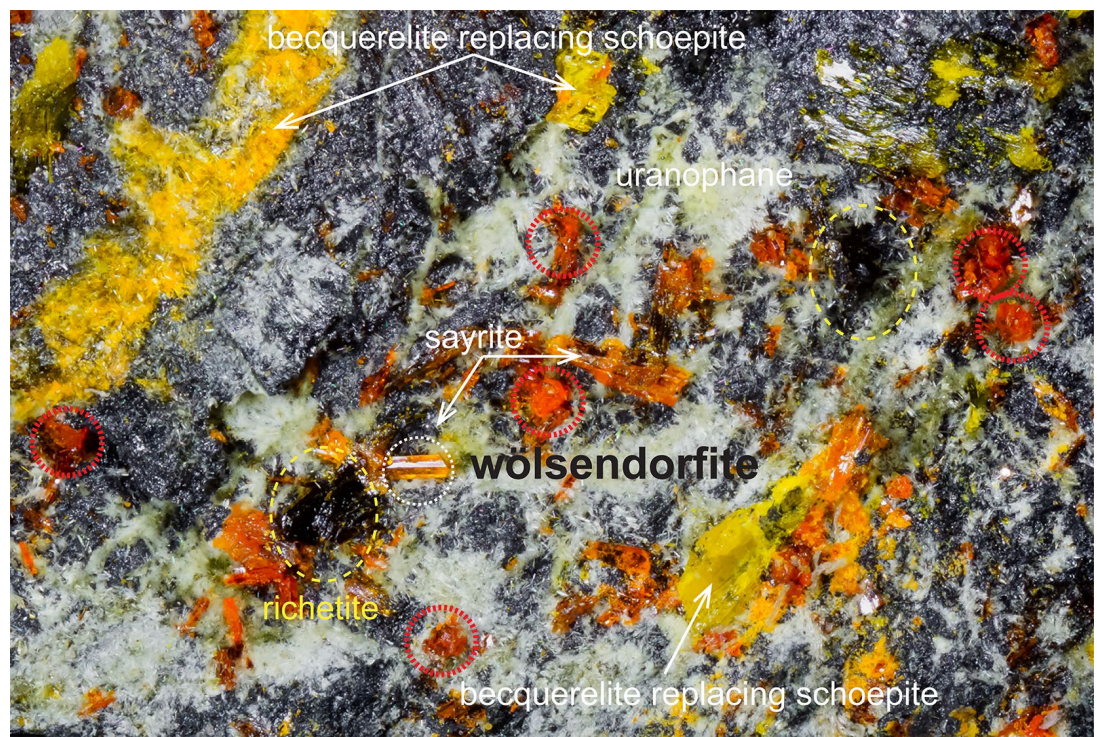

Fig. 3 Mineral association (type I) involving studied wölsendorfite crystal (marked by red dashed circle at the center of the photography) on the holotype specimen of sayrite (RGM 13944) deposited in the collections of the Royal Museum for Central Africa in Tervuren (Belgium). The matrix of the specimen consists of more or less massive pitchblende. The horizontal field of view is $2 \mathrm{~mm}$. Photo by Eddy Van Der Meersche.

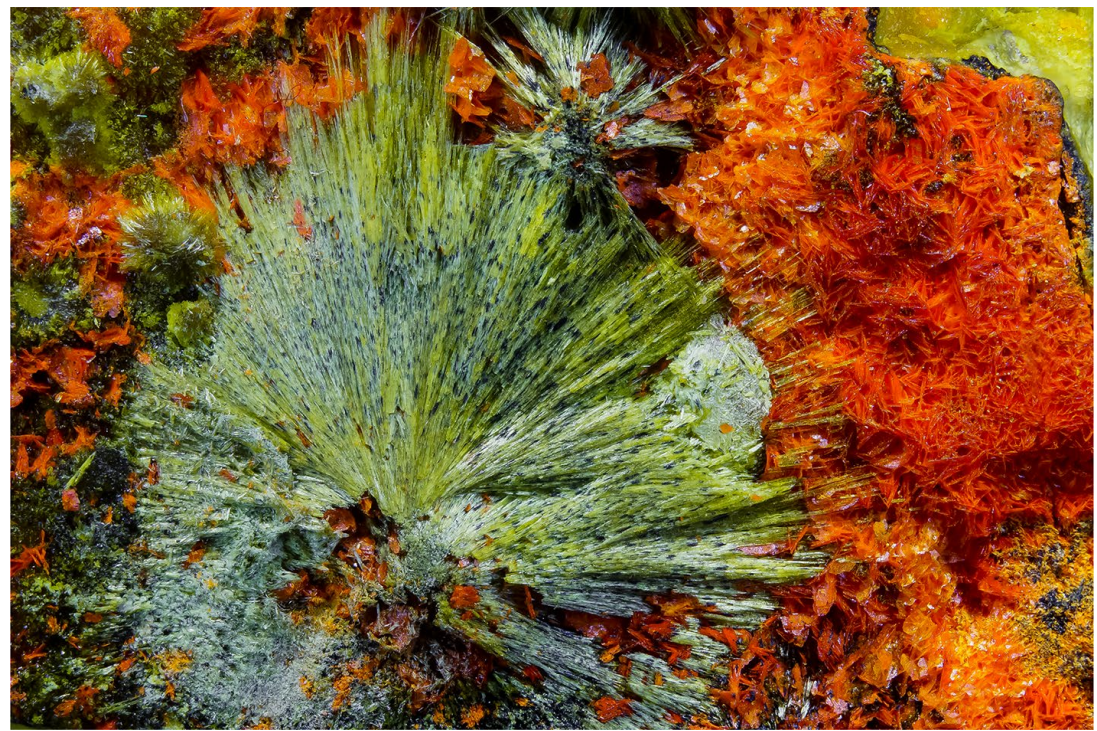

\section{Some remarks on the mineral association of wölsendorfite}

Wölsendorfite belongs to not so abundantly occurring uranyl minerals, although it has been reported from more than thirty localities worldwide. Most usually, it occurs as a part of the massive aggregates of $\mathrm{UOH}$ minerals, usually forming mixtures with other $\mathrm{U}^{6+}$-containing supergene minerals, such as uranyl phosphates (metatorbernite, metaautunite) and uranyl silicates (uranophane- $\alpha$, weeksite, soddyite). These aggregates were called gummites in the past, and this descriptive name has been retained. Wölsendorfite that forms crystals is much rarer and has been reported only from few localities. These include Shinkolobwe mine in Haut -Katanga province, Democratic Republic of Congo (Deliens et al. 1981). The vast of well-crystallized specimens originate from there. Based on the visual observations made on the reliably characterized specimens from the museum collections (MHN Luxembourg and RMCA Tervuren), some remarks can be made on the mineral association that involves wölsendorfite and related minerals and have, hopefully, a wider validity.

As has been noticed, wölsendorfite occurs as a relative late supergene phase in the alteration sequence after pitchblende. The occasional contents of $\mathrm{Ba}^{2+}$ and $\mathrm{Ca}^{2+}$ (see Burns 1999; Sejkora et al. 1997) suggest the role of alteration solutions derived from the weathered host rocks. Those elements are usually not available in the very early stages of uraninite alteration. The late stage of alteration, at least from Shinkolobwe, is usually represented by the presence of wölsendorfite, sayrite and richetite, and time-to-time also becquerelite and less also curite (usually as the massive aggregates). The other uranyl minerals comprise extremely rare

Fig. 4 Mineral association (type II) involving wölsendorfite (reddish -orange) associated with a radial aggregate of sharpite. The Shinkolobwe mine, Haut-Katanga province, the Democratic Republic of Congo, specimen no. RMG2768, Royal Museum for Central Africa, Tervuren, Belgium. The horizontal field of view is $28 \mathrm{~mm}$. Photo by Eddy Van Der Meersche. 
Table 7 Most complex uranyl-oxide hydroxy-hydrate minerals and their characteristic complexity measures including $H$ atoms.

\begin{tabular}{|c|c|c|c|c|c|c|c|}
\hline Mineral & Chemical formula & References & $\begin{array}{l}\text { Space } \\
\text { group }\end{array}$ & $V\left[\AA^{3}\right]$ & $v$ & $\begin{array}{c}I_{G}[\mathrm{bits} / \\
\text { atom] }\end{array}$ & $\begin{array}{c}I_{G, \text { total }}[\mathrm{bits} / \\
\text { cell] } \\
\end{array}$ \\
\hline vandendriesscheite & $\mathrm{Pb}_{1.5}\left[\left(\mathrm{UO}_{2}\right)_{10} \mathrm{O}_{6}(\mathrm{OH})_{11}\right]\left(\mathrm{H}_{2} \mathrm{O}\right)_{11}$ & Burns (1997) & Pbca & 8490 & 672 & 6.39 & 4295.64 \\
\hline gauthierite & $\mathrm{KPb}\left[\left(\mathrm{UO}_{2}\right)_{7} \mathrm{O}_{5}(\mathrm{OH})_{7}\right]\left(\mathrm{H}_{2} \mathrm{O}\right)_{8}$ & Olds et al. (2017) & $P 2_{1} / C$ & 5772 & 520 & 7.02 & 3651.63 \\
\hline wölsendorfite & $\mathrm{Pb}_{6.07} \mathrm{Ca}_{0.68}\left[\left(\mathrm{UO}_{2}\right)_{14} \mathrm{O}_{18}(\mathrm{OH})_{5}\right] \mathrm{O}_{0.5}\left(\mathrm{H}_{2} \mathrm{O}\right)_{12.6}$ & ${ }_{6}$ this paper & Cmcm & 10890 & 346 & 5.78 & 2000.38 \\
\hline richetite & $\begin{array}{l}\left(\mathrm{Fe}^{2+}{ }_{0.31} \mathrm{Mg}_{0.19}\right) \mathrm{Pb}_{4.86}\left[\mathrm{U}^{5+}\left(\mathrm{U}^{6+} \mathrm{O}_{2}\right)_{17} \mathrm{O}_{18}\right. \\
\left.(\mathrm{OH})_{14}\right]\left(\mathrm{H}_{2} \mathrm{O}\right)_{\sim 19.5}\end{array}$ & Plášil (2017) & $P-1$ & 3601 & 279 & 7.13 & 1988.63 \\
\hline schoepite & {$\left[\left(\mathrm{UO}_{2}\right)_{4} \mathrm{O}(\mathrm{OH})_{6}\right]\left(\mathrm{H}_{2} \mathrm{O}\right)_{6}$} & Plášil (2018) & Pbca & 3528 & 344 & 5.43 & 1866.64 \\
\hline
\end{tabular}

sharpite, $\mathrm{Ca}\left[\left(\mathrm{UO}_{2}\right)_{3}\left(\mathrm{CO}_{3}\right)_{3.6} \mathrm{O}_{0.2}\right]\left(\mathrm{H}_{2} \mathrm{O}\right)_{3}$, and urancalcarite, $\mathrm{Ca}\left(\mathrm{UO}_{2}\right)_{3}\left(\mathrm{CO}_{3}\right)(\mathrm{OH})_{6}\left(\mathrm{H}_{2} \mathrm{O}\right)_{3}$. Rutherfordine, $\mathrm{UO}_{2}\left(\mathrm{CO}_{3}\right)$, is ubiquitous and does not necessarily occur with one particular mineral association.

Two specific associations warrant further comments. The first association comprises wölsendorfite, richetite, sayrite, masyuite, becquerelite, uranophane- $\alpha$ and, surprisingly, also schoepite. All those above-mentioned grow on a massive pitchblende. This association is extremely typical and can be easily recognized. One more extensive set of specimens (including that used in the current study) is preserved in RMCA in Tervuren and has been donated to the museum by Roger Van Dooren (La Hulpe, Belgium). It goes about the same mineral collector who donated the holotype specimen of sayrite (RGM 13944). On the fractures of massive uraninite or its veinlets, the most abundant supergene minerals are uranophane- $a$ and becquerelite. There are also some relics of schoepite. Nevertheless, it seems that it is somewhat corroded, i.e., the rest of, at least UOHs, are younger than schoepite. The remaining association includes sayrite and richetite (Fig. 3). Wölsendorfite appears as isolated crystals or their twins. The color is very similar to that of sayrite. In fragments, it was nearly impossible to discern among them without $X$-ray diffraction. The second association (Fig. 4), which is also Ca-rich, is represented by rare mineral sharpite, forming radial aggregates consisting of long-prismatic needle-like crystals, rounded by thick tabular wölsendorfite. The Ba-rich association, at least from Shinkolobwe, comprises distinct minerals, including billietite. Wölsendorfite often forms crusts and partially also isolated crystals, which are, nevertheless, overgrown by uranophane- $\alpha$.

Additionally, the three particularly interesting occurrences of wölsendorfite, have to be mentioned: Slavkovice nearby Nové Město na Moravě, Czechia (Sejkora et al. 1997), uranium deposits Zálesí nearby Javorník and Jelení vrch nearby Bílá Voda (Mrázek, Novák 1984). Sejkora et al. (1997) gave results of qualitative chemical analyses for wölsendorfite, which had been found along with billietite. Interestingly, they do not report the contents of $\mathrm{Ba}$ in wölsendorfite, but $\mathrm{Ca}$ instead. It can be explained that billietite formed independently, before wölsendorfite, which usually forms minute crystals in the cavities of the strongly weathered veinlets of $\mathrm{UOHs}$ and pitchblende. For wölsendorfite from Zálesí and Jelení vrch, only qualitative chemistry has been given. To conclude, the new modern analytical research, including both micro- and trace-elements determination, would be exciting and would help reveal the limits of the metal-cation substitutions in wölsendorfite in general.

\section{Acknowledgments}

I would like to express my thanks for providing me with great microphotographs to Eddy Van Der Meersche (Ghent, Belgium). Simon Philippo (MHN Luxembourg, Luxembourg) and Florias Mees (RMCA Tervuren, Belgium) are highly acknowledged for making samples for the research available. An anonymous referee and Jiři Čejka are acknowledged for their comments. This work was financially supported by the Ministry of Education, Youth and Sports National sustainability program I of the Czech Republic (project No. L01603).

\section{References}

Burns PC (1999) A new complex sheet of uranyl polyhedra in the structure of wölsendorfite. Am Mineral 84: 1661-1673

BURNS PC (2005) $\cup^{6+}$ minerals and inorganic compounds: Insights into an expanded structural hierarchy of crystal structures. Can Mineral 43(6): 1839-1894

BuRns PC, FINCH RJ (1999) Wyartite: Crystallographic evidence for the first pentavalent-uranium mineral. Am Mineral 84: 1456-1460

Burns PC, Finch RJ, Hawthorne FC, Miller ML, Ewing $\mathrm{RC}$ (1997) The crystal structure of ianthinite, $\left[\mathrm{U}_{2}{ }^{4+}\right.$ $\left.\left(\mathrm{UO}_{2}\right)_{4} \mathrm{O}_{6}(\mathrm{OH})_{4}\left(\mathrm{H}_{2} \mathrm{O}\right)_{4}\right]\left(\mathrm{H}_{2} \mathrm{O}\right)_{5}$ : a possible phase for $\mathrm{Pu}^{4+}$ incorporation during the oxidation of spent nuclear fuel. J Nucl Mater 249: 199-206

Deliens M, Piret P, Comblain G (1981) Les minéraux secondaires d'uranium du Zaïre. Published by Musée Royal de l'Afrique Central, Tervuren, Belgium.

EWING RC (2015) Long-term storage of spent nuclear fuel. Nature Mater 14: 252-257

FINCH RJ, EwING RC (1992) The corrosion of uraninite under oxidizing conditions. J Nucl Mater 190: 133-156

FINCH RJ, MuRAKAMI T (1999) Systematics and paragenesis of uranium minerals. In: Burns PC, Finch RJ (eds) Uranium: Mineralogy, Geochemistry and the Environment. Rev Mineral Geochem 38: 91-180

Finch RJ, Burns PC, Hawthorne FC, Ewing RC (2006) Refinement of the crystal structure of billietite $\mathrm{Ba}\left[\left(\mathrm{UO}_{2}\right)_{6}\right.$ $\left.\mathrm{O}_{4}(\mathrm{OH})_{6}\right]\left(\mathrm{H}_{2} \mathrm{O}\right)_{8}$. Can Mineral 44: 1197-1205

GuRZHIY VV, PLÁšIL J (2019) Structural complexity of natural uranyl sulfates. Acta Crystallogr B 75: 39-48

GurzhiY VV, KuporeV IV, Kovrugin VM, MurashKo MN, Kasatkin AV, Plasil J (2019) Crystal chemistry and structural complexity of natural and synthetic uranyl selenites. Crystals 9: 639

Klingensmith AL, Deely KM, Kinman WS, Kelly V, Burns PC (2007) Neptunium incorporation in sodium-substituted metaschoepite. Am Mineral 92: 662-669 
KRIVOVICHEV SV (2012) Topological complexity of crystal structures: quantitative approach. Acta Crystallogr A 68: 393-398

KRIVOVICHEV SV (2013) Structural complexity of minerals: information storage and processing in the mineral world. Mineral Mag 77: 275-326

KRIVOVICHEV SV (2014) Which inorganic structures are the most complex? Angew Chem Int Ed Engl 53: 654-661

KRIVOVICHEV SV (2016) Structural complexity and configurational entropy of crystals. Acta Crystallogr B 72: 274-276

KRIVOVICHEV SV (2020) Polyoxometalate clusters in minerals: review and complexity analysis. Acta Crystallogr B 76, 618-629

KRIVOVICHEV SV, PLÁšIL J (2013) Mineralogy and crystallography of uranium. In: Burns P. C., Sigmon G. E. (eds) Uranium: From Cradle to Grave. Mineralogical Association of Canada Short Courses 43, pp 15-119

Kubatko KA, Helean K, Navrotsky A, Burns PC (2006) Thermodynamics of uranyl minerals: Enthalpies of formation of uranyl oxide hydrates. Am Mineral 91: 658-666

Lussier AJ, Lopez RAK, Burns PC (2016) A revised and expanded structure hierarchy of natural and synthetic hexavalent uranium compounds. Can Mineral 54: 177-283

MAHER K, BARgar JR, Brown GE JR (2013) Environmental speciation of actinides. Inorg Chem 52: 3510-3532

MrÁZEK Z, NovÁK M (1984) Secondary minerals of uranium from Zálesí and Horní Hoštice in the Rychlebské hory Mts., northern Moravia. Acta Mus Moraviae, Sci Nat 69: 7-35 (in Czech)

Murakami T, Ohnukı T, Isobe H, Sato T (1997) Mobility of uranium during weathering. Am Mineral 88: 888-899

O'HARE PAG, LEWIS BM, NGUYEN SN (1988) Thermochemistry of uranium compounds XVII. Standard molar enthalpy of formation at $198.15 \mathrm{~K}$ of dehydrated schoepite UO3.0.9H2O. Thermodynamics of (schoepite + dehydrated schoepite + water). J Chem Thermodyn 20: $1287-1296$

Olds TA, Plášll J, Kampf AR, ŠKoda R, Burns PC, ČEJKA J, BouRgoIn V, Boulliard J-C (2017a) Gauthierite, $\mathrm{KPb}\left[\left(\mathrm{UO}_{2}\right)_{7} \mathrm{O}_{5}(\mathrm{OH})_{7}\right] \cdot 8 \mathrm{H}_{2} \mathrm{O}$, a new uranyl-oxide hydroxy-hydrate mineral from Shinkolobwe with a novel uranyl-anion sheet topology. Eur J Mineral 29: 129141

Olds TA, PlášIl J, Kampf AR, Simonetti A, Sadergaski LR, Chen YS, Burns PC (2017b) Ewingite: Earth's most complex mineral. Geology 45: 1007-1010
Pagoaga MK, Appleman DE, Stewart JM (1987) Crystal structures and crystal chemistry of the uranyl oxide hydrates becquerelite, billietite, and protasite. Am Mineral 72: 1230-1238

Petríiček V, Dušek M, Palatinus L (2014) Crystallographic computing system JANA2006: General features. Z Kristallogr 229: 345-352

PLÁšIL J (2014) Oxidation-hydration weathering of uraninite: the current state-of-knowledge. J Geosci 59: 99-114

PLÁ̌IL J (2017) Crystal structure of richetite revisited: Crystallographic evidence for the presence of pentavalent uranium. Am Mineral 102: 1171-1175

PLÁšIL J (2018a) Uranyl-oxide hydroxy-hydrate minerals: their structural complexity and evolution trends. Eur J Mineral 30: 237-251

PLÁŠIL J (2018b) The crystal structure of uranyl-oxide mineral schoepite, $\left[\left(\mathrm{UO}_{2}\right)_{4} \mathrm{O}(\mathrm{OH})_{6}\right]\left(\mathrm{H}_{2} \mathrm{O}\right)_{6}$, revisited. J Geosci 63: 65-73

Plášll J, Sejkora J, Ondruš P, Veselovský F, Beran P, GoLIÁŠ V (2006) Supergene minerals in the Horní Slavkov uranium ore district, Czech Republic. J Czech Geol Soc 51: 149-158

PlÁšil J, SEJKora J, ČEJKa J, Škoda R, Goliáš V (2009) Supergene mineralization of the Medvědín uranium deposit, Krkonoše Mountains, Czech Republic. J Geosci 54: $15-56$

PlÁšIL J, Kampf AR, ŠKoda R, ČEJKA J (2018) Nollmotzite, $\mathrm{Mg}\left[\mathrm{U}^{\vee}\left(\mathrm{U}^{\vee} \mathrm{O} \mathrm{O}_{2}\right)_{2} \mathrm{O}_{4} \mathrm{~F}_{3}\right] \cdot 4 \mathrm{H}_{2} \mathrm{O}$, the first natural uranium oxide containing fluorine. Acta Crystallogr B 74: 362-369

Plášll J, Kampf AR, Olds TA, Sejkora J, ŠKoda R, Burns PC, ČEJKA J (2020) The new K, Pb-bearing uranyl -oxide mineral kroupaite: Crystal-chemical implications for the structures of uranyl-oxide hydroxy-hydrates. Am Mineral 105: 561-568

PROTAS J (1957) La wölsendorfite, nouvelle espèce uranifère. C R Hebd Séan Acad Sci 244: 2942-2944

RIGAKU (2019) CrysAlis CCD and CrysAlis RED. Oxford Diffraction Ltd, Yarnton, Oxfordshire, UK

Sejkora J, Mazuch J, Abert F, Šrein V, Novotná M (1997) Supergene mineralization of the Slavkovice uranium deposit in western Moravia. Acta Mus Moraviae, Sci Nat 81: 3-24 (in Czech)

SHELDRICK GM (2015) Crystal structure refinement with SHELXL. Acta Crystallogr C 71: 3-8 